\title{
On Dual-Mode of Trade-Consumer Show: A Case Study of GTPE
}

\author{
Xiao Xuan, Wu Jianhua \\ School of Geography \& Tourism, Guangdong University of Financial \& Economics, Guangzhou, China \\ Email: adelaxiao@126.com, wujianhua304@126.com
}

Received 28 August 2014; revised 30 September 2014; accepted 23 October 2014

Academic Editor: Shaodan Luo, Wuhan Irvine Culture and Communications, China

Copyright (C) 2014 by authors and Scientific Research Publishing Inc.

This work is licensed under the Creative Commons Attribution International License (CC BY). http://creativecommons.org/licenses/by/4.0/

(c) (i) Open Access

\section{Abstract}

The purpose of this paper is to introduce a dual-mode of trade-consumer show, which is a new mode that was applied in Guangzhou \& Taiwan Products Expo广州台湾产品博览会 (GTPE). The paper puts forward the definition and illustrates features of this dual-mode, and analyzes the merits, risks as well as countermeasures through the case of GTPE. Study findings indicate the dual-mode of trade-consumer show may trigger the innovations in exhibition theme planning.

\section{Keywords}

Dual-Mode of Trade-Consumer Show, Mode Innovation, Guangzhou \& Taiwan Products Expo

\section{Introduction}

With the flourishing of MICE industry, China has seen remarkable progress in exhibition theme planning. But there are still many problems, such as ambiguous positioning, bad repetitions, etc. This essay suggests a new mode-dual-mode of trade-consumer show, hoping that it may prompt the innovations in exhibition theme planning.

\section{Literature Review}

The earliest systemic classification of exhibition was given by Morrow (1997: p. 14), who classified them into three categories: trade shows, consumer shows and combination shows, according to exhibit types, exhibitors, visitors and admission constraints. Since then, well-known exhibition organizations have announced their classifications for statistics purpose, such as The Glossary of Meetings, Conventions and Exhibitions Industry (jointly 
established by IAEE and CIC), UFI Calculation Standards and Definitions, and Exhibition Terminology, ISO 25639:2008. With all the different terms used in the classifications, the exhibitions can be somehow classified into the above mentioned three categories.

Chinese literature about exhibition-theme planning fits into three categories: 1) articles on regional exhibition studies (e.g. Hu \& Peng, 2009); 2) articles introducing best practices in developed countries (e.g. Li, 2009); and 3) textbooks on MICE theme planning (e.g. Hua, 2004), which suggested some approaches of exhibition-theme planning, and remarked on given examples. Non-Chinese literatures tend to regard exhibitions as part of special events, and study their theme planning through the lens of marketing, such as Joe Goldblatt's (2002) 5W's to Produce Consistently Effective Events; Shone and Parry (2004), Yeoman (2004), Allen (2005) and Bowdin (2006) successively worked on the framework of event planning, and Goldblatt (2005) extended the research to the operational level. Yeoman (2004) put forward some suggestions on special event planning through the cultural aspect.

\section{Definition and Features of the "Dual-Mode of Trade-Consumer Show"}

"Dual-mode of trade-consumer show" means trade shows whose sub-themes involve two or more industries, with features of both trade shows and consumer shows as well; in macroscopic view, it's a new combination of a trade show and a consumer show with dual-sub-theme. A Comparison with other modes is illustrated in Table 1.

We'll take Guangzhou \& Taiwan Products Expo 广州台湾产品博览会 ${ }^{1}$ (hereinafter referred to as “GTPE”) for example to explain the "Dual-Mode of Trade-Consumer Show". The GTPE positioning system is designed in the following way: each GTPE contains one or two sub-themes, which are in accord with the general theme, while also fall within the scope of "Taiwan products", hence a complete positioning system. Take the first GTPE for example. It contained two sub-themes involving agriculture and tourism industry (as illustrated in Figure 1). Many other industries in Taiwan are also promising, such as entertainment industry, media industry, electronic consumer goods industry, civilian industry, IT industry, etc. After thorough investigations, we may choose proper industries as sub-themes, with full consideration of the features and life cycles of each industry involved.

\section{Advantages and Risks of the "Dual-Mode of Trade-Consumer Show"}

The "dual-mode of trade-consumer show" sets a higher requirement for theme planning: these sub-themes should strongly appeal to visitors and be able to inter-infiltrate and integrated into one general theme. The designer should consider the internal links between these sub-themes, and also the industries' developing rules.

The advantages and risks of this mode are displayed in Table 2.

Now, there are two modes similar to "dual-mode of trade-consumer show": one is exhibitions involved in two or more industries that belong to the same category; the other is combination shows (usually focus on one industry) appealing to both professional visitors and consumers (Table 3). Some of their measures in visitor organizing can be adopted in "dual-mode of trade-consumer show", too.

The following measures could be used in "dual-mode of trade-consumer show":

1) To set transition zones. The transition zone displays exhibits fitting to both trade show sub-theme and consumer show sub-theme, or exhibits appealing to professional visitors and general visitors. The $1^{\text {st }}$ GTPE set transition zones with agro-tourism enterprises, institutions and associations, which fit to the sub-theme of tourism and the sub-theme of agricultural products as well. In the transition zones, there were also "Taiwan Fruit Show" and "Taiwan Food Street", which successfully attracted both professional visitors and general ones. The transition zones may effectively lead the visitor flows, and enhance the interchanges and interactions between two show parts.

2) To ensure a good environment for trade negotiation and for consumption through proper divisions of professional visitors and general ones. Besides setting period/date for professional and general visitors, there are some measures more flexible, such as: a) to utilize the traffic fluctuation during the working date and weekends. Traffic for consumers show usually reaches its peaks in weekends, while professionals can attend the show any day during the week, so the ideal show period is from Thursday to Sunday; b) to utilize a functional exhibition floor layout, which will help in proper divisions, too.

\footnotetext{
${ }^{1}$ It is a sub-branch of Guangzhou Fair, jointly organized by Guangzhou municipal government and China Foreign Trade Center. The $18^{\text {th }}$ Guangzhou Fair was held in Guangzhou from Aug. $26^{\text {th }}$ to $29^{\text {th }}$, 2010, covering an area of nearly 50,000 square meters with over 2300 booths. It provided about one hundred booths for Taiwan agricultural products.
} 
Table 1. Comparison of "dual-mode of trade-consumer show” and other modes.

\begin{tabular}{|c|c|c|c|c|}
\hline Index Mode & Trade show & Consumer show & $\begin{array}{l}\text { Combination } \\
\text { show }\end{array}$ & $\begin{array}{l}\text { Dual-mode of trade-consumer } \\
\text { show }\end{array}$ \\
\hline Professionality & High & Low & Medium & $\begin{array}{l}\text { High for trade show part and } \\
\text { low for consumer show part }\end{array}$ \\
\hline $\begin{array}{l}\text { Requirement for } \\
\text { visitors' professional } \\
\text { knowledge }\end{array}$ & High & Low & High & $\begin{array}{l}\text { High for trade show part and } \\
\text { low for consumer show part }\end{array}$ \\
\hline Industries involved & Usually only one & Usually only one & Usually only one & Two or more simultaneously \\
\hline $\begin{array}{l}\text { Target visitors' } \\
\text { profiles }\end{array}$ & $\begin{array}{l}\text { Professionals mostly } \\
\text { specialized in the exhibit } \\
\text { products' designing, } \\
\text { developing, manufacturing, } \\
\text { sales and service }\end{array}$ & $\begin{array}{l}\text { Mass consumers } \\
\text { who can afford to } \\
\text { buy the exhibits }\end{array}$ & $\begin{array}{l}\text { Professionals in the industry } \\
\text { and general public }\end{array}$ & $\begin{array}{l}\text { Combination of professional } \\
\text { visitors, buyers and mass } \\
\text { consumers }\end{array}$ \\
\hline $\begin{array}{l}\text { Marketing } \\
\text { objectives }\end{array}$ & $\begin{array}{l}\text { Mainly to show products, } \\
\text { establish business links and } \\
\text { stimulate the wholesale } \\
\text { business. Retail business may } \\
\text { not be expected }\end{array}$ & $\begin{array}{l}\text { Site Selling is laid } \\
\text { more emphasis }\end{array}$ & $\begin{array}{l}\text { Focus more on site selling, } \\
\text { but also make effort to } \\
\text { show product, establish } \\
\text { business links and stimulate } \\
\text { the wholesale business }\end{array}$ & $\begin{array}{l}\text { Product display, business } \\
\text { socialization, wholesale and } \\
\text { retail business }\end{array}$ \\
\hline Consumptivity & Weak & Strong & Strong & $\begin{array}{l}\text { Weak for trade show part and } \\
\text { strong for consumer show part }\end{array}$ \\
\hline Examples & $\begin{array}{c}\text { Die \& Mould India } \\
\text { International Exhibition, } \\
\text { International Electronic } \\
\text { Circuits Exhibition }\end{array}$ & $\begin{array}{l}\text { Japan Jewellery } \\
\text { Fair, HKTDC } \\
\text { Food Expo }\end{array}$ & $\begin{array}{l}\text { International Travel Expo } \\
\text { (Hong Kong) 香港国际旅 } \\
\text { 游展, International Wine \& } \\
\text { Spirits Fair (Hong Kong) } \\
\text { 香港国际美酒展 }\end{array}$ & GTPE \\
\hline
\end{tabular}

Table 2. Advantages \& risks of the "dual-mode of trade-consumer show”.

\section{Advantages}

- Some professional visitors of trade show may attend the consumer show as well, hence a great boost to on-site selling of consumer show;

- Helps to prompt the interchange and industry amalgamation. Generally speaking, those industries involved in consumer show have greater potential to infiltrate and amalgamate with other industries.

\section{Risks}

The negotiation environment could be ruined: the crowd of non-professional visitors may lead to a mess, making the trade show part also noisy and crowded, and consequently diminishing the exhibition's value for exhibitors and professional visitors.

- It may raise the exhibitor's operational cost: the exhibitors are busy with reception of both professional visitors and non-professional ones, which means more work and higher cost in operation.

- Limited flow between trade show and consumer show: the trade show part and consumer show part may be separated into two exhibitions and lack interchange, which will diminish the exhibition's value, and affect the exhibition brand.

Table 3. Operations in similar modes.

\begin{tabular}{|c|c|c|c|}
\hline Similar Modes & Explanations & Examples & Measures in visitor organizing \\
\hline $\begin{array}{l}\text { Exhibitions } \\
\text { involved in two } \\
\text { or more } \\
\text { industries that } \\
\text { belong to the } \\
\text { same category }\end{array}$ & $\begin{array}{l}\text { Exhibitions involved in two } \\
\text { or more industries, which } \\
\text { both belong to trade show or } \\
\text { consumer show. These } \\
\text { industries either enjoy tight } \\
\text { links between each other, or } \\
\text { just belong to one large } \\
\text { industry }\end{array}$ & $\begin{array}{l}\text { Cross-strait Modern Agriculture Expo 海峡两岸花卉 } \\
\text { 博览会暨台湾农产品博览会 (Zhangzhou, 2008), } \\
\text { International Coal and Mining, Machinery, } \\
\text { Technology and Equipment Expo 中国国际煤炭工业 } \\
\text { 暨矿山机械设备博览会 (Beijing, 2010) } \\
\text { Chicago Boat, Sports \& RV Show (Chicago,2012), } \\
\text { Malaysia International Food \& Beverage Trade Fair } \\
\text { (Kuala Lumpur, Malaysia, 2012) }\end{array}$ & $\begin{array}{l}\text { Similar to simple trade shows } \\
\text { or simple consumer shows }\end{array}$ \\
\hline $\begin{array}{l}\text { Combination } \\
\text { shows appealing } \\
\text { to both } \\
\text { professional } \\
\text { visitors and } \\
\text { consumers }\end{array}$ & $\begin{array}{l}\text { Exhibitions involved in } \\
\text { industries catering to both } \\
\text { mass consumers and } \\
\text { professional buyers }\end{array}$ & $\begin{array}{l}\text { International Travel Expo 国际旅游博览会 (Hong } \\
\text { Kong, 2012), China Watch \& Clock Fair 中国钟表展 } \\
\text { (Shenzhen, 2012), Taiwan Trade Fair 台湾交易会 } \\
\text { (Nanjing, 2010), West-Taiwan-Strait Auto Expo 海峡 } \\
\text { 西岸汽车博览会 (Xiamen, 2012) }\end{array}$ & $\begin{array}{l}\text { - Holding a professional forum } \\
\text { or trade fair during the show; } \\
\text { Dividing the show time into } \\
\text { two parts: "period/date for } \\
\text { professionals" and "period/ } \\
\text { date for public" }\end{array}$ \\
\hline
\end{tabular}




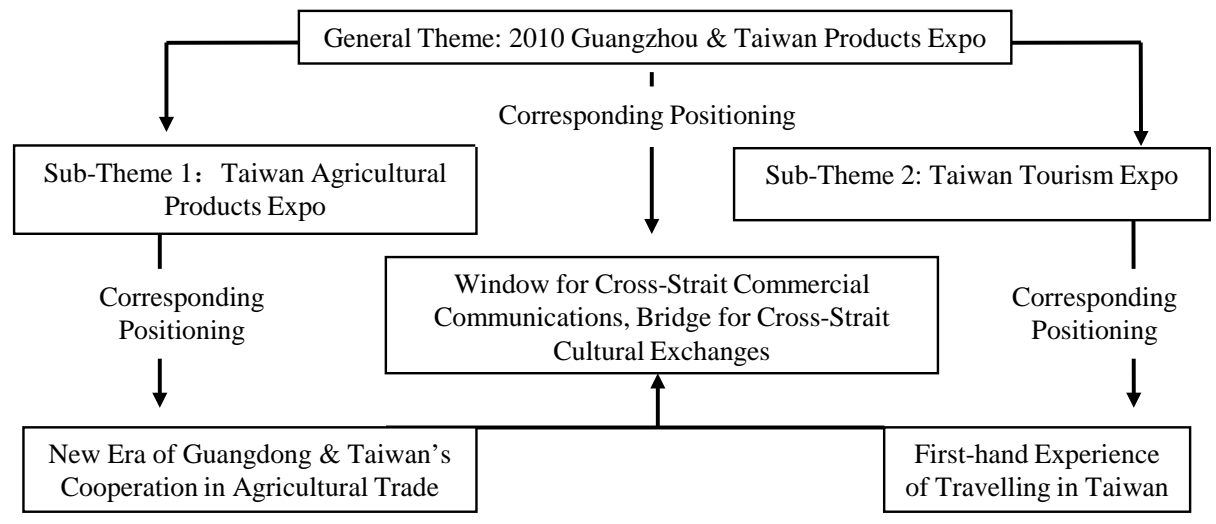

Figure 1. Positioning system of 1st GTPE.

As a new mode, the "dual-mode of trade-consumer show" makes a good exploring step, in spite of its uncertainty and risks. As part of Guangzhou Fair, GTPE provided about one hundred booths and got good remarks from exhibitors and visitors. The most distinguished features of this mode are the conversion of professional visitors and consumers, and promotion on the interchange and industry amalgamation.

\section{References}

Hu Chunlin 胡春林, \& Peng Diyun 彭迪云 (2009). Shenzhen huizhanye fazhan de xianzhuang, wenti yu duice 深圳会展业 发展的现状、问题与对策 [SZ Exhibition Industry Development’s Present Situation, Problem and Countermeasure]. Tequ Jingji, 2, 26-27.

Hua Qiansheng 华谦生 (2004). Huizhan cehua yu yingxiao 会展策划与营销. [Planning and Marketing of Conference and Exhibition]. Guangzhou: Guangdong Jingji Chubanshe.

Joe, G. (2002). Special Events, Twenty-First Century Global Event Management. Hoboken: John Wiley \& Sons, Inc.

Li Zhiling 李智玲 (2009). Deguo huizhanye fazhan de xin qushi ji qishi 德国会展业发展的新趋势及启示 [Enlightenment from Germany MICE Industry]. Chengshi Wenti, 2, 87-90.

Morrow, Sandra L. (1997). The Art of the Show: An Introduction to the Study of Exposition Management. Dallas: IAEM Foundation. 
Scientific Research Publishing (SCIRP) is one of the largest Open Access journal publishers. It is currently publishing more than 200 open access, online, peer-reviewed journals covering a wide range of academic disciplines. SCIRP serves the worldwide academic communities and contributes to the progress and application of science with its publication.

Other selected journals from SCIRP are listed as below. Submit your manuscript to us via either submit@scirp.org or Online Submission Portal.
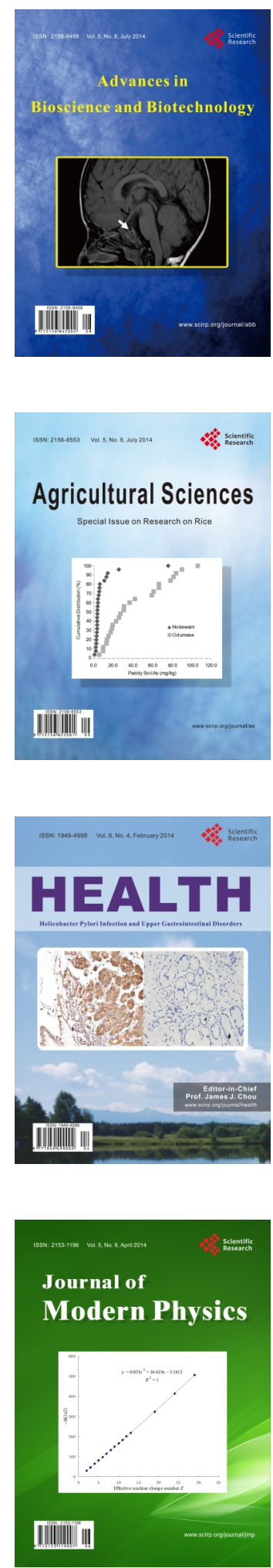
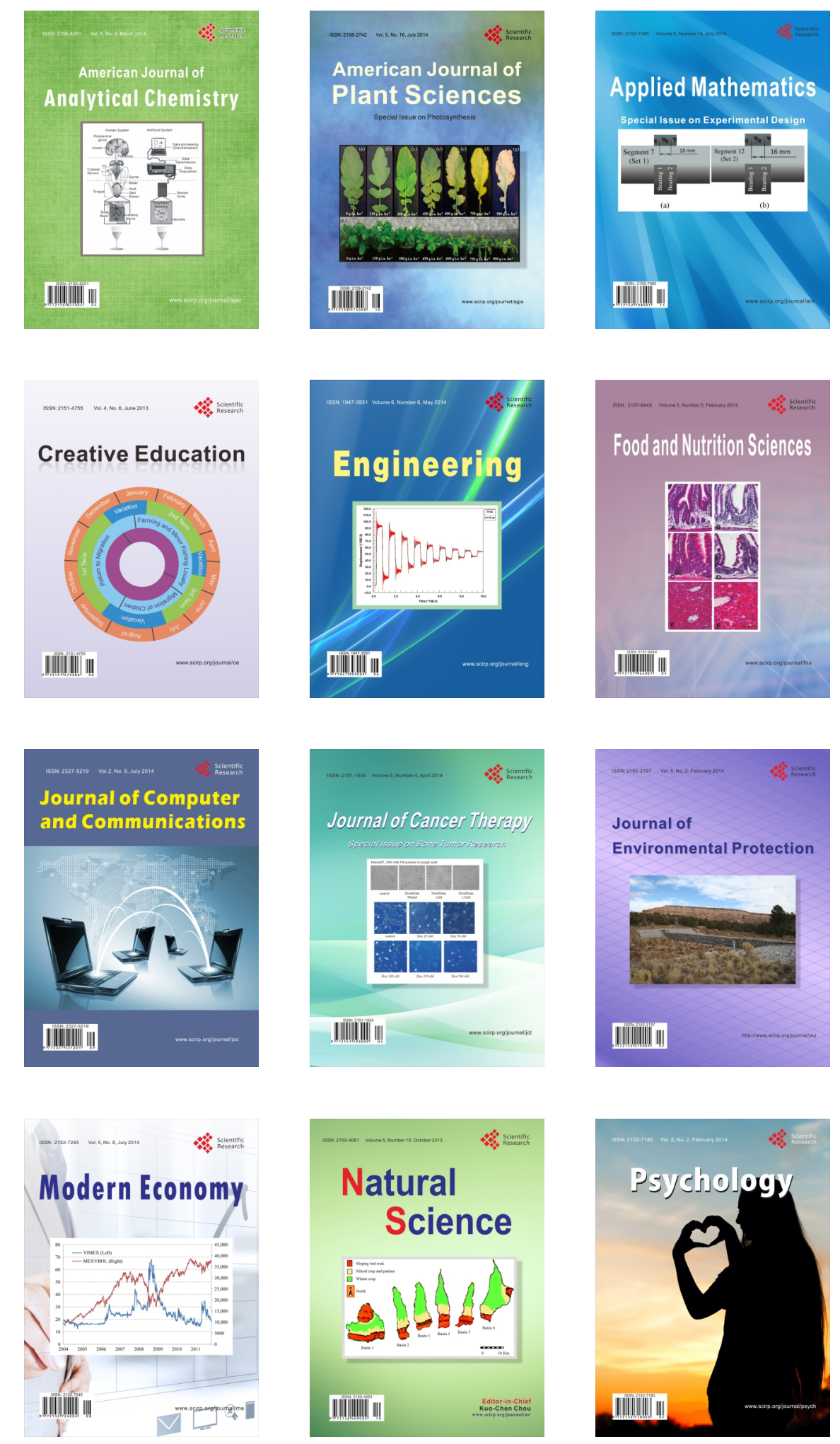